\title{
CADMIUM EXPOSURE VIA FOOD CROPS: A CASE STUDY OF INTENSIVE FARMING AREA
}

\author{
Raagheni Munisamy, Sharifah Norkhadijah Syed Ismail and Sarva Mangala Praveena \\ Department of Environmental and Occupational Health, \\ Faculty of Medicine and Health Sciences, Universiti Putra Malaysia, Malaysia
}

Received 2013-06-22, Revised 2013-08-31; Accepted 2013-09-02

\begin{abstract}
Cadmium (Cd) is ubiquitous in environment and may enter food chain through intense application of phosphate fertilizers to agricultural crops. A cross-sectional study was conducted at Kuala Terla and Blue Valley farming villages, Cameron Highlands to determine cadmium concentration in vegetables and soil and to determine the health risks among respondents. A total of 87 respondents were selected based on inclusive and exclusive criteria. A set of pre-tested questionnaires utilized to obtain socio-demographic information and to predict health risks faced by the respondents based on their vegetable ingestion rate. The Average Daily Dose (ADD) and Target Hazard Quotient (THQ) were determined in this study. Convenient sampling method was employed to obtain 15 paired soil and vegetable samples. Cadmium concentration in the samples was acid digested prior analysis using Flame Atomic Absorption Spectrophotometer (FAAS). The mean \pm standard deviation concentrations of Cd in vegetable samples were $0.13 \pm 0.082 \mathrm{mg} \mathrm{kg}^{-1}$, within the acceptable range specified by Malaysia Food Regulation $1985\left(1 \mathrm{mg} \mathrm{kg}^{-1}\right)$. For sol samples, the mean \pm standard deviation concentration of Cd was $2.78 \pm 2.83 \mathrm{mg} \mathrm{kg}^{-1}$. Eight out of 11 soil samples exceed the permissible limit of $\mathrm{Cd}$ outlined by The Dutch Standard $\left(1 \mathrm{mg} \mathrm{kg}^{-1}\right)$. The findings on THQ demonstrated that all respondents are within the acceptable non-carcinogenic health risk (THQ<1). The results also exhibit that there is no correlation between cadmium in soils and vegetables. There are unlikely potential adverse health impacts arising from $\mathrm{Cd}$ through vegetables consumption in this study. Respondents are advised to have a medical check-up in order to determine $\mathrm{Cd}$ body burden thus eliminating the risks of acquiring cadmium related diseases.
\end{abstract}

Keywords: Cadmium, Intensive Farming, Vegetables, Soil, Health Risks, Cameron Highlands

\section{INTRODUCTION}

The district of Cameron Highlands $\left(4^{\circ} 28^{\prime} \mathrm{N}\right.$, $\left.101^{\circ} 23^{\prime} \mathrm{E}\right)$, Pahang, Malaysia amid the lofty peaks of BanjaranTitiwangsa, lies between 1070 to $1830 \mathrm{~m}$ above sea level and altogether covers about 71200 hectares. The area experiences mild temperature, ranging from 14 to $24^{\circ} \mathrm{C}$ throughout the year, making it very conducive for the growth of a wide range of subtropical crops. The recorded average rainfall here is about $2660 \mathrm{~mm}$ and it is well spread throughout the year with peaks in May and October (Abdullah et al., 2005) and the humidity is high without any marked dry season (Barrow et al., 2009).

Most of the areas in Cameron Highlands can be classified as steep lands, with more than $66 \%$ of the land having gradients greater than $20^{\circ}$. Steep lands are generally not recommended for agriculture, but the favorable cool climate has encouraged the growth of several agricultural activities in the area. In 1997, about $86 \%$ of the area was still covered with forest. As time moves on, extensive areas of Cameron Highlands were intensively used for vegetable cultivation. Out of 5251 ha of land use for agricultural purposes in 1997, land cultivated with vegetables was the most widespread $(47 \%)$, followed by tea $(44 \%)$, flowers $(7 \%)$ and fruits (1\%) (Abdullah et al., 2005).

Lately, flower cultivation has increased at the expense of vegetables. During the $1960 \mathrm{~s}$ and $1970 \mathrm{~s}$, most of the vegetables and flowers were grown for local markets. Agricultural sector accounts for $61 \%$ of the

Faculty of Medicine and Health Sciences, Universiti Putra Malaysia, Malaysia 
employment in Cameron Highlands (Abdullah et al., 2005). However, the ancient farming system is now no more on place as it permits lower income with poor outcome in Cameron Highlands and as for now, there is an intensive form of agricultural system being practiced especially for the cultivation of vegetables, flowers and tea just to experience more benefits. Most of the vegetables are grown on terraces cut into granite hills. Often these terraces are on the C-horizon or saprolite.

Large inputs of chicken manure, chemical fertilizer and other agrobiocides are added to sustain vegetable cultivation as part of intensive cropping cycle. Much of these inputs contain heavy metals and these elements tend to accumulate over time in soil by which the overall process of plant growth depends on the nutrients cycle; absorbing trace elements from soil to plant. Vegetable consumption is one of the pathways by which these said heavy metals gain access into our body and subsequently increase health risks. Heavy metals that persist in the ambient environment are non-biodegradable and have the tendency to accumulate in different organs through food crops consumption. Excessive accumulation of dietary heavy metals such as zinc, cadmium, copper, chromium and lead over time may lead to serious health problems (Kanakaraju et al., 2007). Heavy metals are ubiquitous in environment and exist in various forms. However, only cadmium is stressed in this study as it is highly toxic to humans.

According to (Jiao et al., 2012), long-term use of phosphate fertilizers and micronutrients could cause the arsenic (As), cadmium $(\mathrm{Cd})$ and lead $(\mathrm{Pb})$ content of the cropland soils to rise if the products used contains high level of these elements (for Cd, greater than $10 \mathrm{mg} \mathrm{kg}^{-1}$ ). On the other hand, (UNEP, 2006), in its report stated that input of cadmium to farmland by atmospheric deposition and application of phosphate fertilizers and sewage sludge has been an important concern. The significance of cadmium accumulation in agricultural topsoil has been demonstrated in several European countries.

According to (ATSDR, 2011), chronic exposure to cadmium may lead into serious health problems such as renal nephropathy, skeletal lesions Itai-itai disease and even cancer. Acute symptoms of cadmium poisoning include gastrointestinal problems and mild anemia.

In recent years, the adverse effects of pesticides, inorganic fertilizers, animal manure, mining activities and atmospheric deposition towards the agricultural soil has become an issue of concern. They have prompted numerous questions into the health and safety of consumers. The heavily contaminated soils may pose long terms risks to ecosystems and also human health via increased uptake and accumulation of heavy metals in plant tissues (Khairiah et al., 2006). The adverse effects may be experienced by the people as they consume vegetables accumulated with heavy metals.

The effects of heavy metals are not immediate; being said so the potential of consumers to contract a disease caused by heavy metals may take a long way. At the same time, the effects can be mild and scarce as well. Thus it is of utmost important for us to ensure that the soil that is used for agricultural and farming purposes are of better quality to ensure physical health. Apart from being a hill station and a famous tourist spot, Cameron Highlands is also well known for its intensive agricultural activity that is being the main source of income for most of its residents. Moreover, the food crops harvested here are being sold in the nearby markets nevertheless being exported. Naser et al. (2010), reported that due to steep terrain in the highlands, cultivation of crops requires extensive land levelling and terracing to ensure the maximum usage of the limited area. This land levelling activities results in growing crops on subsoil stored through large inputs of both organic and inorganic fertilizers.

In addition, the agricultural activities performed in this area are aided by chemical control. It remains as the most popular approach for pest and disease problems contracted by the plants whereby the frequency of application is once a week and get height during wet season. Besides, the intensive cropping cycles of vegetables in Cameron Highlands are also accompanied by high inputs of fertilizers and other agro biocides such as lime, burnt rice husk, soymeal, compound fertilizers and chicken dung. Much of these inputs slowly accumulate over time in the soil (Khairiah et al., 2009).

Crop plants may adsorb heavy metals from the growth medium and consequently produce detrimental effects to human health via food crops ingestion (Khairiah et al., 2009). Although some of the heavy metals or trace elements are essential for our health, it is important to uphold its level in our body due to their toxicity properties.

As such, the level of heavy metals present in the soil and crops grown has to be monitored regularly to promote the wellbeing of our community and this could be done through this project. Cadmium is selected as a major parameter to assess health risks among the local inhabitants living at the agricultural zones of Cameron Highlands. This is due to the fact that cadmium is highly toxic to human in excess and may pose detrimental effects to human health. Human activities and intensive farming with massive use of pesticides and phosphate fertilizers increases the availability of cadmium in soil. This study measures the health risks of local inhabitants from cadmium exposure via consumption of food crops at intensively farmed area. The health risks arising from cadmium exposure has been highlighted in this study. An intensive farming system is being applied by the local 
farmers through the usage of fertilizers and pesticides in Cameron Highlands. These chemicals are utilized intensively so as to control the pest infection besides enhancing crops' growth. As a matter of fact, although these chemicals are known to produce beneficial impacts as desired by the farmers, the hazardous content of those chemicals are still unknown especially the concentration of the cadmium which could sustain in the environment.

The uptake and bioaccumulation of cadmium in vegetables through soil may pose detrimental effects to humans through food chain. Sharma et al. (2008), indicated that for most of people, the main route of exposure to heavy metals is through diet except for occupational exposures at related industries. Heavy metals such as cadmium $(\mathrm{Cd})$ and lead $(\mathrm{Pb})$ have been proved as carcinogens. High concentrations of heavy metals copper $(\mathrm{Cu})$, cadmium $(\mathrm{Cd})$ and lead $(\mathrm{Pb})$ in fruits and vegetables were related to high prevalence of upper gastrointestinal cancer.

By conducting this study, the health risks of cadmium exposure through food crops consumption can be identified and interventions could be made to control the usage of those chemicals in trace amount that is presumably beneficial to our health. This study aims to determine health risks from cadmium exposure via consumption of food crops at intensively farmed area, Cameron Highlands.

\section{MATERIALS AND METHODS}

\subsection{Study Design}

This project was carried out at Blue Valley and Kuala Terla farming villages, Cameron Highlands, Pahang. Cameron Highlands is a major vegetables growing area in Peninsular Malaysia (Fig. 1).

This research was conducted based on cross-sectional study design. Soil and vegetable samples were collected to determine the concentration of cadmium so as to assess the health risks of cadmium exposure through food chain among the local inhabitants of Blue Valley and Kuala Terla villages. Convenient sampling strategy was used to select vegetable farms and soil samples. All the vegetables planted on selected vegetable farms were collected besides the soils where the vegetable samples were collected using convenient sampling method as well.

Purposive sampling was employed to select the study respondents with the most reliable criteria. Eighty Seven $(\mathrm{n}=87$ ) respondents both male and female were carefully recruited from Blue Valley and Kuala Terla Farming villages with informed consent to assess their health risks. There were roughly 400 residents living in the Kuala Terla farming village and 300 residents in Blue Valley where the study samples were drawn from. Indian and Chinese were dominant in the area followed by the primitive group (Orang Asli). There were approximately 5 household members in each family. The study respondents were primarily Indian adults, aging more than 18 years old who consume the vegetables grown in their area. Study respondents living adjacent to farming areas are prone to consume more vegetables and may subject to increased cadmium exposure and thus they are chosen for conducting this study. This study was commenced for two weeks starting January 2013 until February 201.

\subsection{Site Description}

The area has a mountainous topography. Most of the vegetables were grown on terraces cut into the granite hills. These terraces are commonly sited on the Chorizon or saprolite (Fig. 2). Acid ingenious rocks, particularly granite form one of the most important parent rocks of soils in Cameron Highlands. Soils developed on these parent materials make up approximately $50 \%$ of the areas. This granite is typically of a coarse-grained porphyritic to mica granite of upper Triassic to Cretaceous Age. As the two villages are the pioneers for vegetable cultivation in Cameron Highlands, the local populations over the two villages were sampled.

\subsection{Data Collection}

\subsubsection{Questionnaire}

The questionnaire takes into account previous findings from the literature and was adapted from (UNEP, 2008)Guidance of identifying populations at risk from mercury exposure to assess health risks arising from cadmium exposure. Respondents filled in the self-administered questionnaires by themselves. Information required was also obtained through direct interviews with the respondents by the researcher. The questionnaire elicits information on personal and socio-demographic information, environmental risk factors, dietary habits of the subjects, health status and other relevant factors. The following information is elicited in the questionnaire:

- Section A: Personal and Socio-demographic Information - Date of birth, gender, ethnicity, religion, marital status, education level and occupation, height, weight and body mass index (BMI)

- Section B: Drinking Water Sources-Water source, method of water disinfection, distance to the water source

- Section C: Vegetable Consumption Frequency

- Section D: Health Status Assessment

- Section E: Other Possible Sources of Cadmium Exposure-Fertilizers and pesticides handling, smoking habit and alcohol consumption 
Raagheni Munisamy et al. / American Journal of Applied Sciences 10 (10): 1252-1262, 2013

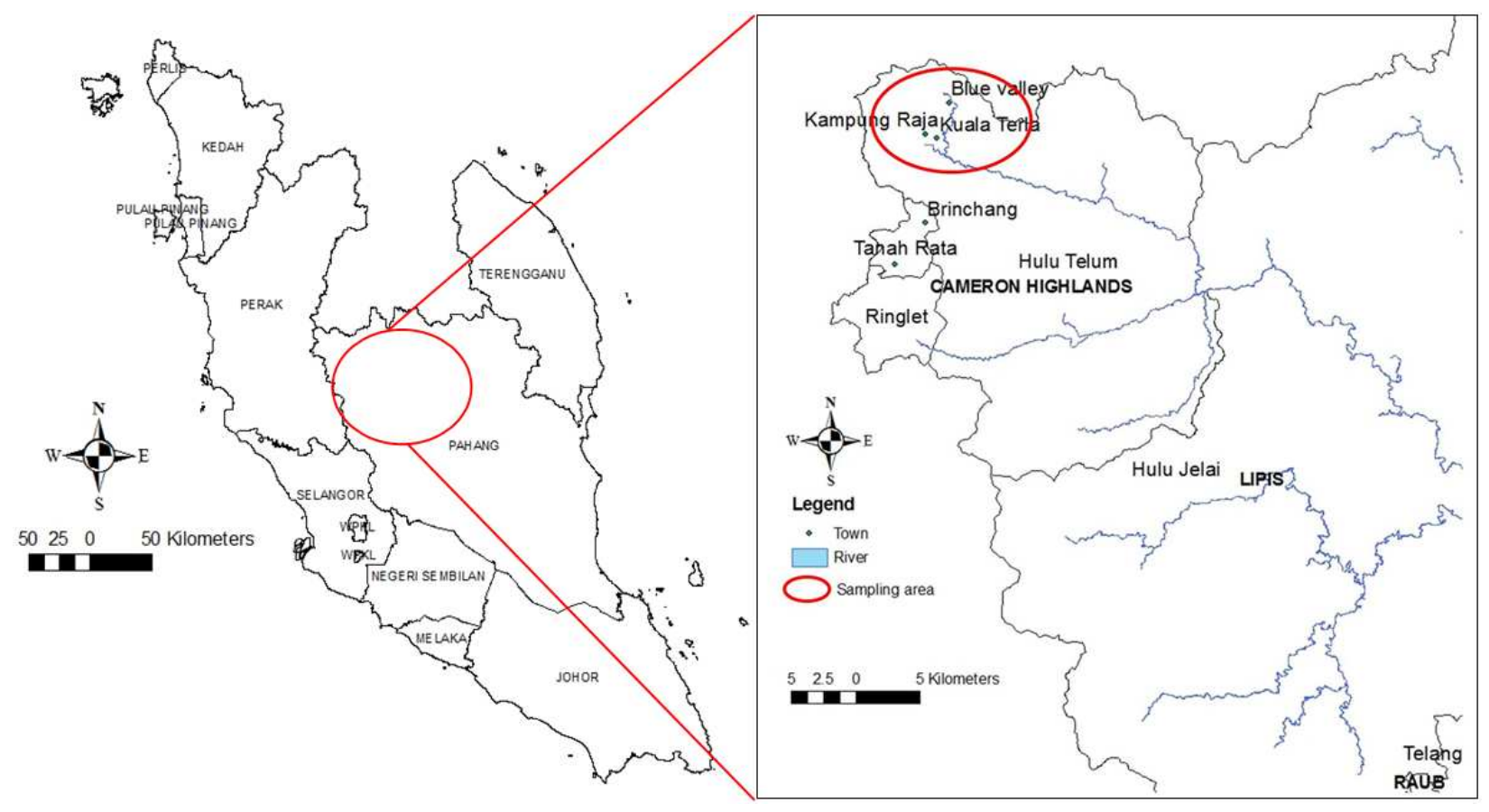

Fig. 1. Sampling site, cameron highlands

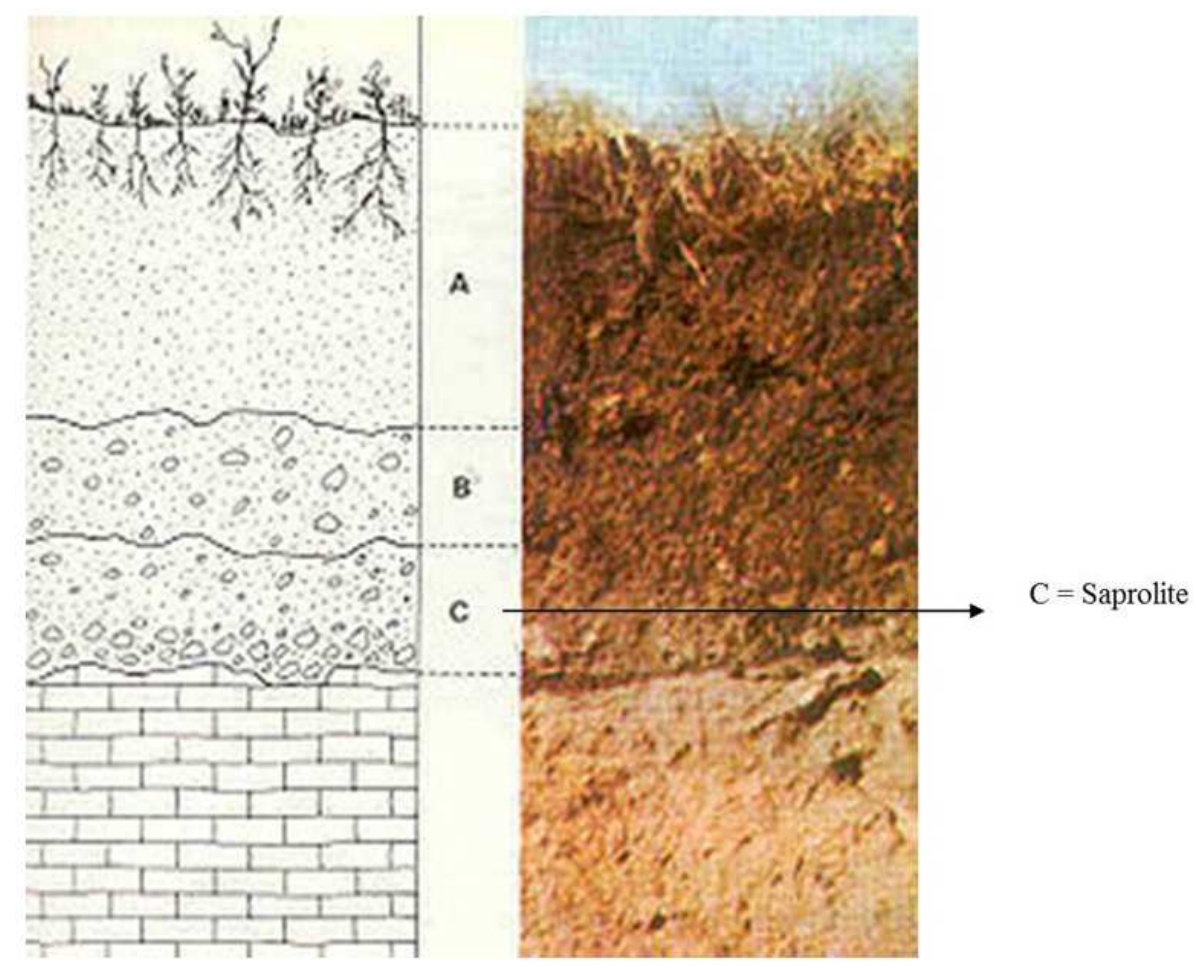

Fig. 2. Saprolite/C-Horizon cut into granite hill 


\subsection{Vegetables and Soil Sampling}

Vegetables were harvested using stainless steel knife. Harvested vegetables were placed in polyethylene plastic bags. Vegetables grown at the farm were collected by taking into account regional consumption practices of the local inhabitants. Three types of vegetables sampled in this study; onion spring, lettuce and parsley. They were collected at the same spot as the soil samples. Vegetables collected in plastic bags were cut into small pieces with stainless steel knife and washed in tap water followed by deionized water. Later, they were packed in a brown study to avoid contamination and made to dry, in oven at $65^{\circ}$ to $70^{\circ} \mathrm{C}$ until a constant weight. The dried vegetables were then crushed, grounded using pastel and mortar, weighed using an analytical balance and kept enclosed in beaker for analysis (Mohamed, 2002). Soil at each sampling site, were collected using convenient sampling method, with paired soil and plant samples taken at 0-20 cm depth (Zhuang et al., 2009). Each soil sample was collected using shovel and kept in a plastic bag. Soil samples collected in plastic bags from the field were transferred to clean plastic sheets and airdried at room temperature for a week.

\subsection{Sample Analysis}

\subsubsection{Vegetable Sample Analysis}

Grounded vegetable samples, $0.5-1.0 \mathrm{~g}$ were placed in volumetric flasks and subsequently digested with $10 \mathrm{~mL}$ of $0.25 \mathrm{M} 65 \% \mathrm{HNO}_{3}$ in an oven at $70-80^{\circ} \mathrm{C}$. The digestion proceeds until clear solution was obtained. After cooling down, the suspensions were filtered with Whatman no.42 filter study. The filtrate was adjusted to $10 \mathrm{ml}$ with distilled water. Digested samples were then labeled and stored in refrigerator to be analyzed using Flame Atomic Absorption Spectrophotometer (FAAS) (Khan et al., 2006).

\subsection{Soil Sample Analysis}

Fifteen (15) Air-dried soil samples collected from different farm plots were grinded and sieved. One gram of soil from each samples were placed in volumetric flask. Fifteen milliliters of $65 \% \mathrm{HNO}_{3}$ were added and the samples were swirled to wet the sample. The samples were stand overnight. The next day, samples were heated in an oven at $60-70^{\circ} \mathrm{C}$ to be digested. After 4 hours of digestion, the digested samples were let to be cooled and filtered with Whatman no.42 filter study. The filtrates were diluted up to $50 \mathrm{ml}$ using $0.25 \mathrm{M}$ of $65 \% \mathrm{HNO}$. Digested samples were then labeled and stored in refrigerator to be analyzed using FAAS. The analytical method used in this study measures the total content of $\mathrm{Cd}$ in vegetables and soils.

\subsection{Data Analysis}

Descriptive statistics were used to analyze the sociodemographic information of respondents, frequency of vegetable intake in grams, possible cadmium poisoning signs and health-related problems, respondents' activities and occupation, other possible exposure to cadmium sources, Target Hazard Quotient (THQ), as well as cadmium concentration in both soils and vegetables. Correlation tests were performed to determine the relationship between concentration of cadmium in soils with concentration of cadmium in vegetables.

\subsection{Health Risk Assessment}

Cadmium is a probable human carcinogen, but there is still lack of sufficient data to estimate carcinogenic risk quantitatively. Non-carcinogenic health risks from consumption of vegetables by the local inhabitants were assessed based on the Target Hazard Quotient (THQ). THQ values were calculated by comparing the average daily intake dose (ADD) of cadmium to the corresponding reference dose (RfD) as in Equation (1). A THQ below 1 means that the exposure population is unlikely to experience obvious adverse effects (Cao et al., 2010):

$\mathrm{HQ}=\mathrm{ADD} / \mathrm{RfD}$

ADD was calculated as in Equation (2) (Zhuang et al., 2009):

$\mathrm{ADD}=(\mathrm{C} \times \mathrm{IR}) / \mathrm{BW}$

Where:

$\mathrm{C}=(\mu \mathrm{g} / \mathrm{kg}$, on fresh weight basis): Mean cadmium concentration in vegetables

IR $=(\mathrm{g} /$ person/day $)$ : Ingestion rate of vegetables,

$\mathrm{Bw}=$ Bodyweight

THQ $=$ Target Hazard Quotient

$\mathrm{ADD}=$ Average Daily Dose $(\mathrm{mg} / \mathrm{kg} /$ day $)$

$\mathrm{RfD}=$ Oral Reference Dose $(\mathrm{mg} / \mathrm{kg} / \mathrm{day})$ Oral reference dose is $1 \times 10^{-3}(\mathrm{mg} / \mathrm{kg} / \mathrm{d})$ for $\mathrm{Cd}$ (IRIS, 2007). 
The Ingestion Rate (IR) (g/person/day) was calculated as frequency of intake (conversion factor) $\mathrm{x}$ serving size $\mathrm{x}$ total number of servings $\mathrm{x}$ weight of food in one serving (Norimah et al., 2008). The Transfer Factor (TF) or Bioaccumulation Factor (BAF) is an index of the ability of the vegetable to accumulate cadmium with respect to its concentration in the soil substrate. The value was calculated as $\mathrm{C}_{\text {plant }} / \mathrm{C}_{\text {soil }}$ (Zhuang et al., 2009), represent cadmium concentration in edible part of vegetables $\left(\mathrm{C}_{\text {plant }}\right)$ and soils $\left(\mathrm{C}_{\text {soil }}\right)$ respectively.

\section{RESULTS}

\subsection{Socio-Demographic Information of Respondents}

Study respondents were mainly recruited from Kuala Terla (Batu 49) and Blue Valley farming villages. Respondents consist of 49 female $(56.3 \%)$ and 38 male $(43.7 \%)$. The majority of study respondents were Indians (78.2\%), age between 50 to 69 (36.8\%). About 43.7\% of study respondents having normal Body Mass Index (BMI) which is between $18.5-24.9 \mathrm{~kg} / \mathrm{m}^{2}$. Among those who participated in this study, $73.6 \%$ are married. With regard to education, most of the study respondents $(41.4 \%)$ have studied until secondary level. Most of the respondents are farmers and at most they do plant crops apart from their daily job (Table 1).

Study respondents might have exposed to cadmium from other sources of exposure despite consumption of contaminated vegetables. Drinking water contamination, exposure to fertilizers and pesticides, smoking habit and alcohol consumption may increase disease burden as well (WHO, 2010). Table 2 indicates that most of the respondents $(47.1 \%)$ use rain water for their daily activities followed by tap water $(41.4 \%)$ and river water (11.5\%) for their household chores. Cadmium exposure from drinking-water is relatively unimportant compared with exposure from the diet (WHO, 2010).

However, impurities in the zinc of galvanized pipes and solders in fittings, water heaters, water coolers and taps can sometimes lead to increase cadmium levels in drinking-water (WHO, 2010). In addition, 25.3\% of respondents in this study were exposed to chemicals and $35.6 \%$ of respondents were exposed tofertilizers or pesticides from their working environment. Eight $(8 \%)$ of respondents do smoke and $33.3 \%$ of them consume alcohol. Tobacco smoking is an important additional source of exposure for smokers. Since one cigarette contains approximately 1 to $2 \mu \mathrm{g}$ of cadmium, smoking one pack per day results in a daily uptake of cadmium that approximates the amount derived from food (Bernard, 2008).

Approximately $73.6 \%$ of study respondents consume vegetables 2-3 times per day. About $11.5 \%$ of study respondents consume vegetables once a day. There are $6.9 \%$ of study respondents who consume vegetables 2-4 times and 5-6 times per week respectively in their daily diet. Respondents who consumed vegetables 2-3 times per day, once a day and 5-6 times per week were classified as frequent vegetable eaters while those who consumed vegetables 2-4 times in a week and once a week were classified as non-frequent vegetable eaters.

The frequency of vegetable intake is important to assess the health risks of respondents. Relevant data are required to conclude whether the respondents are safe through consumption of vegetables grown at cadmium polluted agricultural sites. In order to answer this question, THQ was calculated. At first, the vegetable ingestion rate was determined through frequency of vegetable intake assessed in questionnaire. The vegetable ingestion rate was then used to determine the ADD for each respondent. The ADD was required to estimate respondents' non-carcinogenic health risks (THQ).

\subsection{Cadmium Concentration in Vegetables}

Seven (7) out of fifteen vegetable samples collected indicate the presence of $\mathrm{Cd}$. The Mean \pm Standard Deviation (SD) cadmium concentration in the samples were $0.13 \mathrm{mg} \mathrm{kg}^{-1} \pm 0.082$. The Mean \pm $\mathrm{SD}$ of Cd concentration in onion spring was $0.18 \mathrm{mg}$ $\mathrm{kg}^{-1} \pm 0.10$ followed by lettuce $\left(0.086 \mathrm{mg} \mathrm{kg}^{-1} \pm 0.40\right)$ and parsley $\left(0.087 \mathrm{mg} \mathrm{kg}^{-1} \pm 0.057\right)$. High concentration of $\mathrm{Cd}$ in onion spring was possibly related to high phosphate fertilizer application. Leafy vegetables such as lettuce are generally considered to accumulate cadmium to a higher extent than roots, tuberous and fruit vegetables (Zhuang et al., 2009), which is due to the fact that leafy vegetables have high translocation, high transpiration and also fast growth rates. In addition, they are susceptible to physical contamination by soil dust and splash because of their high foliar surface areas (Zhuang et al., 2009). However, the presence of cadmium in 7 out of 15 vegetable samples does not exceed the permissible level as regulated by the Malaysian Food Regulation, 1985 (1 $\left.\mathrm{mg} \mathrm{kg}^{-1}\right)$ (Fig. 3). 
Raagheni Munisamy et al. / American Journal of Applied Sciences 10 (10): 1252-1262, 2013

Table 1. Socio-demographic information of respondents

\begin{tabular}{|c|c|c|c|c|}
\hline Variable & $\mathrm{N}$ & $\%$ & Mean \pm SD & Range \\
\hline Age (years): & & & $45.75 \pm 16.16$ & $20-85$ \\
\hline $20-29$ & 20 & 23.00 & & \\
\hline $30-49$ & 28 & 32.20 & & \\
\hline $50-69$ & 32 & 36.80 & & \\
\hline$>69$ & 7 & 8.00 & & \\
\hline \multicolumn{5}{|l|}{ Gender: } \\
\hline Male & 38 & 43.7 & & \\
\hline Female & 49 & 56.3 & & \\
\hline \multicolumn{5}{|l|}{ Race: } \\
\hline Chinese & 19 & 21.8 & & \\
\hline Indian & 68 & 78.2 & & \\
\hline Height $(\mathrm{cm})$ : & & & $164.86 \pm 10.08$ & $148-196$ \\
\hline Weight(kg): & & & $67.51 \pm 15.51$ & $42-140$ \\
\hline BMI $\left(\mathrm{kg} / \mathrm{m}^{2}\right)$ : & & & $24.73 \pm 4.57$ & $15.1-42.3$ \\
\hline$<18.5$ & 10 & 11.5 & & \\
\hline $18.5-24.9$ & 38 & 43.7 & & \\
\hline $25-29.9$ & 30 & 34.5 & & \\
\hline$\geq 30$ & 9 & 10.3 & & \\
\hline \multicolumn{5}{|l|}{ Marital Status: } \\
\hline Single & 19 & 21.8 & & \\
\hline Married & 64 & 73.6 & & \\
\hline Widow/widower & 4 & 4.6 & & \\
\hline \multicolumn{5}{|l|}{ Education: } \\
\hline None & 7 & 8.0 & & \\
\hline Primary & 21 & 24.1 & & \\
\hline Secondary & 36 & 41.4 & & \\
\hline Tertiary & 23 & 26.4 & & \\
\hline
\end{tabular}

Table 2. Other possible exposure sources of cadmium $(\mathrm{N}=87)$

\begin{tabular}{lrr}
\hline Variables & $\mathrm{N}$ & $\%$ \\
\hline Water Source & 36 & 41.4 \\
Tap water & 10 & 11.5 \\
River water & 41 & 47.1 \\
Rain water & & 74.7 \\
Chemical Handling & 65 & 5.7 \\
None & 5 & 12.6 \\
$>1$ times per year & 11 & 5.7 \\
$>1$ times per month & 5 & 1.1 \\
$>1$ times per week & 1 & 64.4 \\
$>1$ times per day & & 9.2 \\
Pesticides/Fertilisers Handling & 56 & 17.2 \\
None & 8 & 8.0 \\
$>1$ times per year & 15 & 1.1 \\
$>1$ times per month & 7 & 8.0 \\
$>1$ times per week & 1 & 90.8 \\
$>1$ times per day & & 1.1 \\
Smoking Habit & 7 & 66.7 \\
Yes & 79 & 6.9 \\
No & 1 & 16.1 \\
Already Quit & & 10.3 \\
Alcohol Consumption & 58 & 6 \\
None & 14 & 9 \\
$>1$ times per year & 9 & \\
$>1$ times per month & & \\
$>1$ times per week & 5 & \\
\hline
\end{tabular}




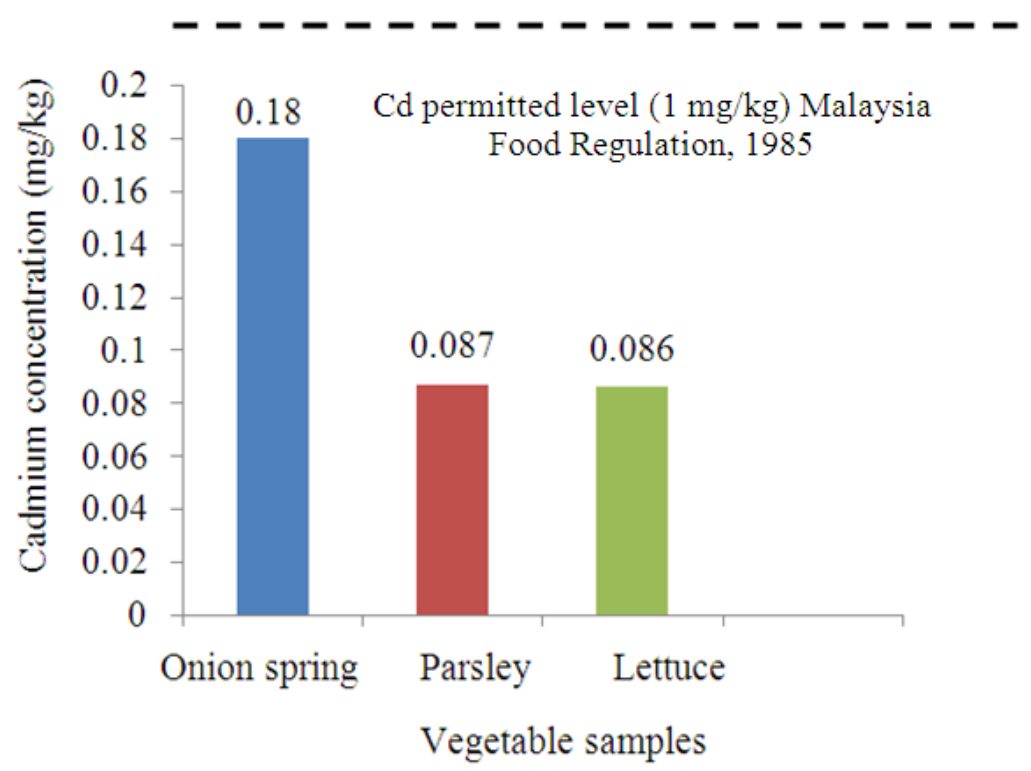

Fig. 3. Cadmium concentration in selected green vegetables

\subsection{Cadmium Concentration in Soil Samples}

Result shows that 11 out of 14 soil samples were detected with cadmium, with the mean concentration of $2.78 \mathrm{mg} \mathrm{kg}^{-1} \pm 2.83(\mathrm{SD})$. Since Malaysia have no soil contamination standard, the $\mathrm{Cd}$ concentration in soil was compared to the Dutch reference value which is $1 \mathrm{mg} \mathrm{kg}^{-1}$ (Fig. 4). There were 8 soil samples contained cadmium concentration more than the specified standard. High concentration of $\mathrm{Cd}$ in soil samples in this study was possibly related to the intense application of phosphate fertilizers to enhance crop production. This result was consistent with (Kirkham, 2006) who indicated that elevated levels of $\mathrm{Cd}$ in soil and excessive concentrations of $\mathrm{Cd}$ in cocoa in Peninsular Malaysia was related to high input of phosphate fertilizers.

\subsection{Relationship Between Cadmium in Soils and Vegetables and Transfer Factor (TF) of Cadmium from Soils to Vegetables}

There was no significant relationship between cadmium in soils and cadmium in vegetables $(\mathrm{p}>0.05)$ (Table 3). The Transfer Factor (TF) of metals was used to evaluate the potential capability of plants to transfer metals from soil to edible tissues. Soil-toplant transfer is one of the key components of human exposure to metals through the food chain. Metals with high TF are more easily transferred from soil to the edible parts of plants than ones with low TF (Luo et al., 2011). Based on a study conducted by (Luo et al., 2011), the TF values for cadmium varied from 0.038 to 1.258 , with a mean of 0.383 , which was the highest among the other metals and was more than 50 times the TFs of copper and lead. Due to the high concentration of exchangeable cadmium in vegetable soils, the cadmium in the edible parts of vegetables probably came from the root uptake from soils.

In this study, lettuce has the highest transfer factor of 0.12 followed by parsley with 0.027 and onion spring with 0.022 which indicates that lettuce has the potential to absorb cadmium readily from soil (Table 4). This was supported by Li et al. (2012), in his study where lettuce has the highest TF for most of the heavy metals. Zhuang et al. (2009), indicated that the transfer factor varies greatly with plant species. It is suggested that $\mathrm{Cd}$ can bind with enzymes instead of $\mathrm{Zn}$ when the two metals simultaneously enter plant cells, as $\mathrm{Zn}$ and $\mathrm{Cd}$ affect nucleic acid metabolism in the same manner. Consequently, $\mathrm{Cd}$ is easier to transfer from soil to the edible part of crops properties compared to $\mathrm{Zn}$. These findings strongly suggest that the transfer of heavy metals from soil to food crops results in relatively high concentration of $\mathrm{Pb}$ and $\mathrm{Cd}$ in rice and vegetables which may affect the human health in near future. 


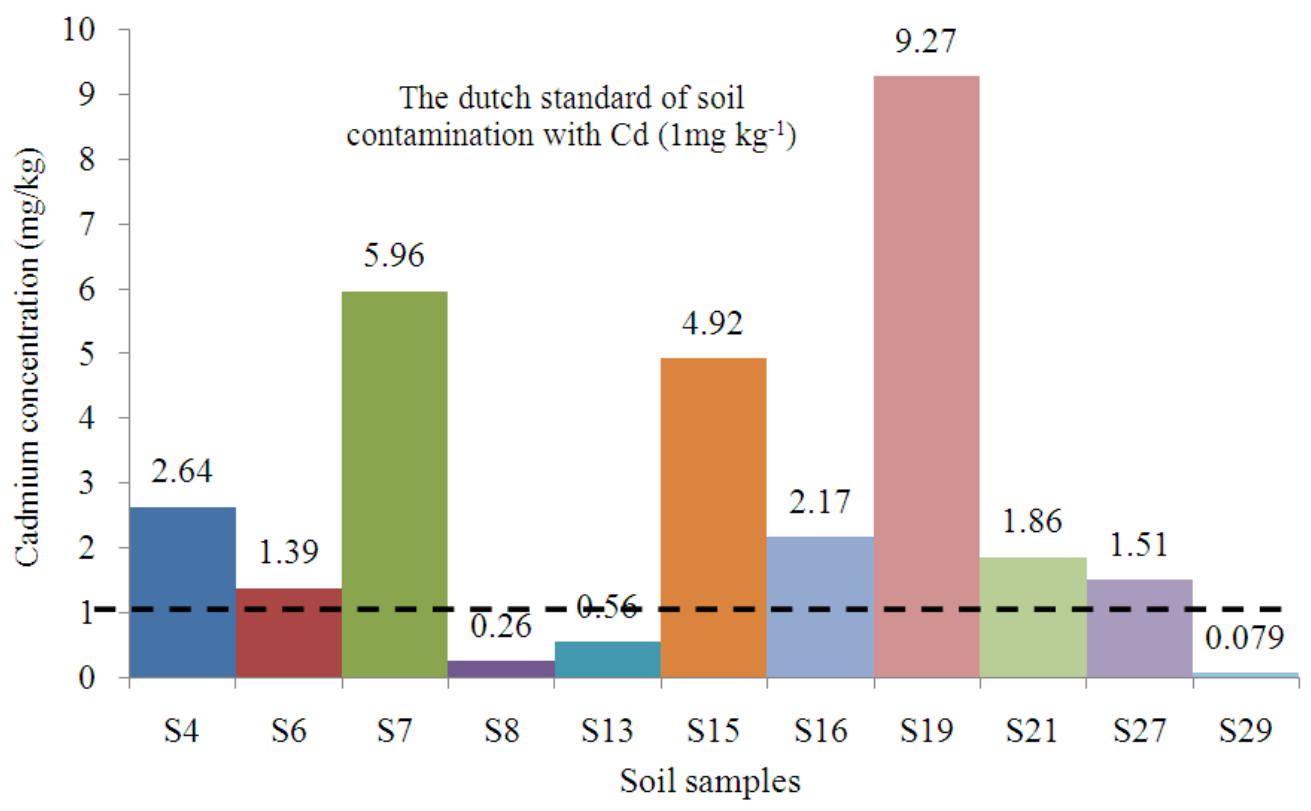

Fig. 4. Cadmium concentration in soil samples

Table 3. The relationship of cadmium in soils and vege-tables

\begin{tabular}{lll}
\hline & \multicolumn{2}{l}{ Cadmium in vegetables } \\
Variables & --1 & $\mathrm{P}$ \\
\hline Cadmium in soil & $\mathrm{R}$ & 0.180 \\
\hline
\end{tabular}

Table 4. TF value of cadmium from soil to vegetables

\begin{tabular}{ll}
\hline Samples & TF \\
\hline Parsley-soil & Mean \pm SD \\
Onion spring-soil & $0.027 \pm 0.0310$ \\
Lettuce-soil & $0.022 \pm 0.0065$ \\
\hline
\end{tabular}

\subsection{Possible Cadmium Poisoning Signs and Health-Related Problems}

Most of the respondents do not experience any adverse effects due to cadmium poisoning except for $17.2 \%$ of respondents who have reported of facing some skin problems followed by gastrointestinal problems (11.5\%) and respiratory problems (10.3\%) (Table 5). Almost all of the study respondents do not exhibit any signs of cadmium poisoning as only $1.1 \%$ of study respondents reported with skeletal, renal, liver and nerve related problems. In addition, $29.9 \%$ of respondents have reported of hair fall and $27.6 \%$ of joint pain. Cadmium accumulates in the human body and especially in the kidneys. Kidney damage (renal tubular damage) is probably the critical health effect from $\mathrm{Cd}$ poisoning
(WHO, 2010). The accumulation of cadmium in the kidney (in the renal cortex) leads to dysfunction of the kidney with impaired reabsorption of, for instance, proteins, glucose and amino acids. It is estimated that $1 \%$ of all smoking women in Sweden with low body iron stores may experience adverse kidney effects due to the cadmium load. Other effects of cadmium exposure are disturbances in calcium metabolism, hypercalciuria and formation of stones in the kidney Nordic Council of Ministers, 2003.

\subsection{Health Risks Encountered by Respondents from Cadmium Exposure via Consumption of Vegetables}

Non-carcinogenic health risk of respondents was calculated using Average Daily Dose (ADD). Later ADD is used to compute the Target Hazard Quotient (THQ). The mean $\pm \mathrm{SD}$ of ADD in this study was $2.54 \times 10^{-4}$ $\pm 1.27 \times 10^{-4} \mathrm{mg} / \mathrm{kg} /$ day (Table 6). All respondents $(\mathrm{N}=$ 87) have the Target Hazard Quotient (THQ) value $<1$ with the Mean \pm SD of $0.254 \pm 0.127$. This indicates that the risk for non carcinogenic health impact of $\mathrm{Cd}$ for these respondents is acceptable. According to (Lalor, 2008), there have been several cases of apparently high exposures to cadmium without accompanying health effects in France, Germany, United Kingdom (UK) and the United States (US). 
Table 5. Health related problems among respondents

\begin{tabular}{lr}
\hline Health problems & Percentage $(\%)$ \\
\hline Skin problems & 17.2 \\
Gastrointestinal problems & 11.5 \\
Respiratory problems & 10.3 \\
Skeletal, renal, liver and & \\
nerve related problems & 1.1 \\
Hair fall & 29.9 \\
Joint pain & 27.6 \\
\hline
\end{tabular}

Table 6. Average Daily Dose (ADD) of respondents

\begin{tabular}{ll}
\hline & Mean \pm SD \\
\hline $\begin{array}{l}\text { Vegetable Ingestion Rate } \\
\text { (IR) (g/person/day) }\end{array}$ & $129.46 \pm 58.19$ \\
Cd concentration & $0.13 \pm 0.082$ \\
in vegetables (mg/kg) & \\
Body weight $(\mathrm{kg})$ & $67.51 \pm 15.51$ \\
ADD (mg/kg/day) & $2.54 \times 10^{-4} \pm 1.27 \times 10^{-4}$ \\
\hline
\end{tabular}

In addition, there may be numerous other confounding factors including cadmium bioavailability differences among vegetables, the percentage absorption of dietary cadmium in a population, genetics, lifestyle, diet and antagonistic or synergistic exposures to other elements, interpretations in "normal" $\beta$-microglobulin and the effect of aging that may influence the occurrence of cadmium poisoning among the respondents.

\section{DISCUSSION}

This study has shown that there are no significant health risks from cadmium exposure via consumption of food crops at intensive farming zone, Cameron Highlands at present. However, this situation might change relative to the upcoming intense agricultural system. Although Cameron Highlands is known to be a massive agricultural zone in Malaysia, the intensive agricultural practices prompt numerous questions to the health and safety of the consumers as the intensive cropping cycles of vegetables are accompanied by high inputs of fertilizers and other agro-biocides such as lime, burnt rice husk, soymeal, compound fertilizers and chicken dung.

This situation is an evident, where half of the vegetable samples were detected with cadmium but within the permissible limit outlined by the Malaysia food regulation, 1985. However, the undetectable level of cadmium in vegetables does not depict that the vegetables are safe to be consumed but there is an alarming warning that more advanced equipment is required to compute exact cadmium concentration in those samples.

Most of the soil samples were detected with the presence of cadmium more than the specified standard. Since Malaysia not yet have any soil contamination guidelines or standard, the cd concentration was compared to the Dutch standard. There were 11 soil samples detected with the presence of cadmium whereby eight out of them exceeded the standard value $\left(1 \mathrm{mg} \mathrm{kg}^{-1}\right)$. This possibly related to the high usage of fertilizers in this area or possibly due to the nature of the soil. Further assessment such as comparing the $\mathrm{Cd}$ value to $\mathrm{Fe}$ or $\mathrm{Al}$ in the soil samples could provide an indication whether $\mathrm{Cd}$ was from the anthropogenic process or from the nature of the soil (Ismail, 2011; Alloway, 1990).

The excessive presence of $\mathrm{Cd}$ in agricultural soils enables vegetables grown on the soil to absorb more cadmium. The availability of $\mathrm{Cd}$ for root uptake of plants increases as the concentration of Cd increases in the soils which is primarily due to the application of phosphate fertilizers. Bioaccumulation of $\mathrm{Cd}$ in vegetables poses a threat to the consumers.

Transfer factor is another way of determining whether there is a probability of cadmium being absorbed by the plants and the results shows that parsley, lettuce and onion spring have such capability to absorb cadmium concentration in soils.

Questionnaire results interpretation shows that the respondents do not face any adverse effects from vegetable consumption although cadmium has been found in both vegetable and soil samples. This is because the adverse effects of cadmium are not immediate. Being said so; it requires long term assessment to identify any possible changes in the health status of the respondents due to cadmium poisoning. More comprehensive assessment is required to assess cadmium poisoning among the respondents from various sources such as smoking, drinking water, consumption of canned foods, grain, rice and job history in order to obtain representative data for determining their health risks.

\section{CONCLUSION}

This study has determined that there were no significant health risks from cadmium exposure via consumption of food crops at intensively farmed area, Cameron Highlands. However, further detailed and comprehensive research should be conducted to determine the exact risk that the study respondents are facing from cadmium exposure through food chain. Moreover, this detailed assessment shall be inclusive of other cadmium exposure sources accompanied. Interventional program such as free medical check-up must also be employed to the local population to determine their body burden with cadmium and other heavy metals that they possibly been exposed to through vegetables. 


\section{ACKNOWLEDGEMENT}

We would like to express our gratitude and highest appreciation to all respondents and farmers from Cameron Highlands and to the staff of Department of Environmental and Occupational Health UPM for their support and cooperation during the data collection and laboratory analyses.

\section{REFERENCES}

Abdullah, W.Y.W., B.Y. Aminuddin and M. Zulkifli, 2005. Modelling pesticide and nutrient transport in the cameron highlands, malaysia agro-ecosystems. Water Air Soil Poll Focus, 5: 115-123. DOI: 10.1007/s11267-005-7407-9

Alloway, B.J., 1990. Heavy Metals in Soils. 1st Edn., Blackie, Glasgow, ISBN-10: 0470215984, pp: 339.

ATSDR, 2011. Case studies in environmental medicine.

Barrow, C.J., N. Weng and T. Masron, 2009. Issues and Challenges of sustainable agriculture in the cameron highlands. Malays J. Environ. Manage., 10: 89-114.

Bernard, A., 2008. Cadmium and its adverse effects on human health. Ind. J. Med. Res., 128: 557-564. PMID: 19106447

Cao, H., J. Chen, J. Zhang, H. Zhang and L. Qiao et al., 2010. Heavy metals in rice and garden vegetables and their potential health risks to inhabitants in the vicinity of an industrial zone in Jiangsu, China. J. Environ. Sci., 22: 1792-1799. DOI: 10.1016/S10010742(09)60321-1

IRIS, 2007. Oral reference dose for Cadmium.

Ismail, S.N.S., 2011. Assessing environmental impacts and siting considerations for landfills in developing countries: A case study of Malaysia. Phd Thesis, Univeristy of East Anglia.

Jiao, W., W. Chen, A. Chang, C. and A. L. Page, 2012. Environmental risks of trace elements associated with long-term phosphate fertilizers applications: A review. Environ. Poll., 168: 44-53. DOI: 10.1016/i.envpol.2012.03.052

Kanakaraju, D., N.A. Mazura and A. Khairulanwar, 2007. Relationship between metals in vegetables with soils in farmlands of Kuching, Sarawak. Malaysia J. Soil Sci., 11: 57-69.

Khairiah, J., J. Habibah, R. Ahmad Mahir, A. Maimon and A. Aminah et al., 2009. Studies on heavy metal deposits in soils from selected agricultural areas of Malaysia. Adv. Environ. Biol., 3: 329-336.

Khairiah, J., K.H. Lim, R. Ahmad-Mahir and B.S. Ismail, 2006. Heavy metals from agricultural soils from Cameron Highlands, Pahang and Cheras, Kuala Lumpur, Malaysia. B. Environ. Contam. Tox., 77: 608-615. DOI: 10.1007/s00128-006-1106-8
Khan, S., Q. Cao, B. Chen and Y. Zhu, 2006. Humic acids increase the phytoavailability of $\mathrm{Cd}$ and $\mathrm{Pb}$ to wheat plants cultivated in freshly spiked contamin soil. J. Soil Sediment, 6: 236-242. DOI: 10.1065/jss2006.08.178

Kirkham, M.B., 2006. Cadmium in plants on polluted soils: Effects of soil factors, hyperaccumulation and amendments. Geoderma, 137: 19-32. DOI: 10.1016/j.geoderma.2006.08.024

Lalor, G.C., 2008. Review of cadmium transfers from soil to humans and its health effects and Jamaican environment. Sci. Total Environ., 400: 162-172. DOI: 10.1016/j.scitotenv.2008.07.011

Li, Q., Y. Chen, H. Fu, Z. Cui and L. Shi et al., 2012. Health risk of heavy metals in food crops grown on reclaimed tidal flat soil in the Pearl River Estuary, China. J. Hazard Mater., 227-228: 148-154. DOI: 10.1016/j.jhazmat.2012.05.023

Luo, C., C. Liu, Y. Wang, X. Liu and F. Li et al., 2011. Heavy metal contamination in soils and vegetables near an e-waste processing site, South China. J. Hazard Mater., 186: 481-490. DOI: 10.1016/j.jhazmat.2010.11.024

Mohamed, E.I.A.S., 2002. Assessment of heavy metal contamination in soils and vegetables in cameron highlands vegetable farms. Master Thesis. Universiti Putra Malaysia.

Naser, H., N. Shil, N. Mahmud, M. Rashid and K. Hossain, 2010. Lead, cadmium and nickel contents of vegetables grown in industrially polluted and non-polluted areas of Bangladesh. Bangladesh. J. Agric. Res., 34: 545554. DOI: 10.3329/bjar.v34i4.5831

Norimah, A.K. Jr, M. Safiah, K. Jamal, S. Haslinda and H. Zuhaida et al., 2008. Food consumption patterns: Findings from the Malaysian Adult Nutrition Survey (MANS). Malays. J. Nutr., 14: 25-39. PMID: 22691762

Sharma, R K., M. Agrawal and F.M. Marshall, 2008. Heavy metal $(\mathrm{Cu}, \mathrm{Zn}, \mathrm{Cd}$ and $\mathrm{Pb})$ contamination of vegetables in urban India: A case study in Varanasi. Environ. Poll., 154: 254-23. DOI: 10.1016/j.envpol.2007.10.010

UNEP, 2006. Interim review of scientific information on cadmium. United Nations Environmental Programme.

UNEP, 2008. Guidance for identifying populations at risk from mercury exposure. United Nations Environmental Programme.

WHO, 2010. Exposure to cadmium: A major public health concern. World Health Organization.

Zhuang, P., M.B. McBride, H. Xia, N. Li and Z. Li, 2009. Health risk from heavy metals via consumption of food crops in the vicinity of Dabaoshan mine, South China. Sci. Total Environ., 407: 1551-1561. DOI: 10.1016/j.scitotenv.2008.10.061 